\title{
DAMPAK PENGGUNAAN BAHAN KEMASAN FOAM \\ TERHADAP LINGKUNGAN
}

Oleh :

\author{
Wiwik Pudjiastuti *)
}

\section{Environmental Impact of the Used of Foam Packaging Material}

\begin{abstract}
Foam is one kind of packaging materials which is developed very quickly and widely used both in developed and developing countries like in Indonesia. The reason is, as a packaging material, foam gives some benefits i.e. leakproofness, light, practice and very cheap comparing with other materials. Otherwise, it will become serious problem when they produced by using blowing agent with high global warming which effect on ozone depletion which is have many harmful effects for the environment and health.
\end{abstract}

Intisari:

Foam merupakan salah satu bahan kemasan yang berkembang cukup pesat serta digunakan cukup luas baik dinegara-negara maju maupun negara berkembang seperti Indonesia. Hal ini disebabkan karena sebagai bahan kemasan, foam memberikan banyak keuntungan antara lain : tahan bocor, ringan praktis, dan harganya sangat murah dibandingkan dengan bahan kemasan lain. Namun hal ini akan menjadi ancaman yang cukup serius bila dalam proses pembuatannya menggunakan blowing agent dengan global warming potential yang tinggi yang berpengaruh terhadapt terjadinya penipisan lapisan ozon yang sangat berbahaya bagi lingkungan dan kesehatan manusia.

\section{PENDAHULUAN}

Di negara maju foam hadir di mana-mana dan dinegara-negara berkembang penggunaannya semakin meningkat. Foam dapat terbuat dari polimer jenis polistirena, polipropilena, polietilena, poliuretan dan lain-lain. Untuk menjadi foam, maka ke dalam polimer tersebut ditiupkan udara salah satunya adalah khlorofluorokarbon (CFC's) sehingga membentuk buih (foam). Foam relatif tahan bocor sehingga menjadi bahan pengemas yang disukai. Pengangkutan barang elektronik yang mudah pecah kerapkali memanfaatkan foam untuk menghindari benturan. Sifat fisik foam yang ringan menguntungkan karena biaya pengangkutan barang nyaris

*) Staf Peneliti Balai Besar Kimia dan Kemasan tidak bertambah. Untuk mengemas makanan foam juga disukai karena memberi kesan praktis dan menjaga suhu makanan dengan baik, jadi makanan panas akan tetap panas dalam kemasan foam. Sebagai bahan kemasan, harga foam sangat murah. Dibandingkan kertas, harga foam ini 2-3 kali lebih murah, dan dibandingkan dengan kemasan isi ulang 5 kali lebih murah. Industri foam terus berkembang karena dalam pembuatannya sangat efisien. Komponen foam adalah $5 \%$ polimer dan sisanya udara.

\section{JENIS-JENIS FOAM.}

Foam terdiri dari berbagai jenis tergantung dari polimer yang digunakan sebagai bahan baku. 


\section{a. Expandable Polystyrene (EPS)}

Foam jenis ini biasanya disebut sebagai styrofoam yang sebenarnya merupakan salah satu merek EPS produksi PT. Dow Chemical Company. Expandable Polystyrene (EPS) adalah bahan berwarna putih yang umumnya digunakan sebagai bantalan (cushion) untuk alat-alat elektronik seperti televisi, komputer dan peralatan stereo. Di samping ini banyak juga digunakan dalam berbagai aplikasi seperti thermos es, dan juga sebagai ke- masan makanan, obat maupun kemasankemasan lain. EPS mempunyai impact dan kekuatan tekan cukup tinggi sehingga mempunyai daya lindung yang sangat baik. EPS merupakan bahan kemasan yang secara ekonomis sangat murah dan sangat ringan. Sifat mekanik EPS sangat tergantung dari berat jenis, yang umumnya dengan meningkatkannya berat jenis maka kekuatannya akan semakin tinggi. Namun demikian bahan baku dan proses pembuatannya juga berpengaruh terhadap sifat mekanik EPS.

Tabel 1. Sifat-sifat umum dari EPS.

\begin{tabular}{|l|l|l|l|}
\hline \multicolumn{1}{|c|}{ Sifat } & \multicolumn{3}{c|}{ Nilai } \\
\hline Berat Jenis, lb/cuft & 1.0 & 2.0 & 3.0 \\
\hline Kekuatan Tekan, psi & $12-17$ & $31-37$ & $52-56$ \\
\hline Kekuatan Tarik, psi & $22-27$ & $56-61$ & $92-95$ \\
\hline Ketahanan terhadap panas & 3.8 & 4.2 & 4.3 \\
\hline
\end{tabular}

Kelebihan EPS :

- Merupakan pelindung yang baik terhadap uap air dalam waktu yang cukup lama

- Dapat digunakan untuk berbagai bentuk produk

- Efisien, karena untuk pembuatan EPS, hanya diperlukan $5 \%$ PS, sisanya udara.

- Ekonomis, karena harga disposable polystyrene 3 kali lebih murah dari pada kertas.

- Convenient dan praktis.

\section{b. Expandable Polyurethane (EPU)}

Expandable polyurethane (EPU) dibuat dari bahan dasar pokok yaitu polyols dan diiscoyanates dengan penambahan beberapa aditif dan bahan tambahan lain.
Keuntungan utama dari poliuretane foam adalah dapat dijadikan menjadi berbagai bentuk, kombinasi dan aplikasi yang luas, lebih kuat, ringan dan lebih mudah digunakan dibandingkan dengan bahan tradisional. Poliuretane foam juga lebih awet dan tidak mudah korosi. Sebagai produk, poliuretan foam dapat mencapai umur antara 3 sampai lebih dari 15 tahun tergantung pada penggunaan akhir. Dengan beratnya yang sangat ringan, poliuretan banyak memberikan keuntungan karena dapat membantu meminimalkan biaya transportasi dan mempermudah konstruksi. EPU (poliuretan foam) banyak digunakan sebagai bantalan (cushioning), kemasan, otomotif peralatan rumah tangga, matras, furniture, coating dan lain-lain 


\section{c. Expandable Polypropylene (EPP)}

Merupakan bahan termoplastik, ringan dengan impact performance yang cukup baik, tahan terhadap bahan kimia dan suhu tinggi. Berat jenis berkisar antara 1.3 sampai 1.9 pcf. EPP merupakan bahan yang tidak mudah pecah dan banyak digunakan untuk kemasan ulang pakai, bahan kemasan tahan terhadap bahan kimia, bantalan komputer, printer, dan lain-lain.

\section{d. Expandable Polyethylene (EPE).}

Expandable polyethylene (EPE) merupakan bahan ringan dengan elastisitas tinggi dengan impact performance yang baik serta tahan terhadap bahan kimia. Berat jenis EPE berkisar antara 2 pcf sampai 3 pcf. EPE banyak digunakan sebagai kemasan ulang pakai, bahan kemasan tahan kimia, helm, dan lain-lain. Selain keempat jenis foam di atas masih banyak lagi bahan baku foam seperti misalnya karet (rubber), PVC, EVA dan lain-lain.

\section{DAMPAK TERHADAP LING- KUNGAN}

Atmosfir terdiri dari beberapa lapisan. Lapisan terendah adalah troposfir dengan ketinggian sampai kira-kira 10 kilo meter dari permukaan bumi yang merupakan wilayah kegiatan manusia. Lapisan berikutnya adalah stratosfir dengan ketinggian antara $10 \mathrm{~km}$ sampai dengan $50 \mathrm{~km}$. Lapisan ini merupakan wilayah penerbangan komersial. Sebagian besar ozon terkonsentrasi pada lapisan stratosfir yaitu pada ketinggian 15 sampai dengan $30 \mathrm{~km}$ di atas permukaan bumi. Ozon adalah molekul yang mengandung 3 atom oksigen, berwara biru serta berbau. Ozon kurang dikenal dibanding normal oksigen.
Tiap 10 juta molekul udara, terdapat kirakira 2 juta oksigen normal. Tetapi hanya 3 molekul ozon. Namun walaupun jumlahnya sangat sedikit, tetapi mempunyai peranan yang cukup penting dalam atmosfir. Lapisan ozon sangat berfungsi menyerap radiasi matahari serta melindungi permukaan planet. Yang terpenting adalah ozon berfungsi meyerap sinar ultra violet yang dikenal dengan sebutan UVB yang sangat berbahaya bagi kesehatan manusia karena dapat menyebabkan kanker kulit, katarak, kerusakan-kerusakan terhadap material tertentu serta kehidupan laut. Pengikisan ozon (ozone depletion) adalah peristiwa berkurangnya lapisan ozon yang disebabkan oleh reaksi kimia kompleks. Bahanbahan yang dominan sebagai penyebab pengikisan ozon adalah bahan-bahan yang mengandung klorin seperti Chloro Fluoro carbon (EFCs), metil bromida dan lain-lain.. Klorin adalah satu bahan kimia yang sangat potensial menyebabkan kerusakan lapisan ozon. Satu atom klorida bebas $(\mathrm{Cl})$ dapat bereaksi dengan gas ozon $\left(\mathrm{O}_{3}\right)$ membentuk molekul oksigen $\left(\mathrm{O}_{2}\right)$ dan klorin monoksida $(\mathrm{ClO})$. Klorin monoksida selanjutnya bereaksi dengan atom oksigen tunggal $(\mathrm{O})$ membentuk atom $\mathrm{CI}$ tunggal dan molekul oksigen lain. Dan akhirnya atom $\mathrm{Cl} \mathrm{ni}$ mulai merusak beberapa atom ozon tanpa merusak dirinya sendiri. Dalam kenyataannya satu atom klorin tunggal dapat merusak 100.000 molekul ozon sebelum turun ke lapisan troposfir. CFC's (chloro fluoro carbon) adalah salah satu bahan kimia yang dapat menjadi penyebab pengikisan ozon. 100 CFC's dapat merusak lebih dari 3 ozon. Hasil penelitian menunjukkan, secara umum penggunaan CFC's menghasilkan $85 \%$ klorin dalam atmosfir. CFC's sebagai bahan kimia mempunyai sifat yang 
sangat stabil, tidak mudah terbakar, dan tidak beracun. Saat ini CFC's banyak digunakan sebagai refrigerant, pelarut blowing agent dan beberapa aplikasi yang lain. Selain CFC's beberapa jenis Fluorocarbon yang juga digunakan sebagai blowing agent adalah HCFC's. Hydro Chloro Fluoro Carbon (HCFC's) merupakan jenis hidrokarbon yang mengandung hidrogen tetapi masih mengandung klorin. Hal ini berarti bahwa HCFCs akan bereaksi dengan troposfir sebelum mulai merusak stratosfer yang merupakan letak lapisan ozon. Masih ada sebagian kecil zat yang merusak stratosfir setelah melewati troposfir, dengan memberikan pengaruh 5 $\%$ terhadap kerusakan lapisan ozon. Ini berarti bahwa HCFC's juga dikategorikan sebagai ODS (Ozon Depletion Substamas). Bahan ini mulai dipakai sebagai blowing agent untuk pembuatan foam (EPS, EPP, maupun poliuretan) sejak tahun 1991. Bahan jenis fluorocarbon lain yang digunakan sebagai blowing agent adalah Hydro Fluoro Carbon (HFC's) yang merupakan satu jenis hidrokarbon yang tidak mengandung khlorine sehingga aman digunakan sebagai blowing agent tanpa menimbulkan kerusakan lapisan ozon. Bahan ini mulai digunakan di Amerika pada tahun 1993. Namun demikian bahan ini masih merupakan bahan dengan global warning potential yang cukup tinggi walaupun Ozon Depletion Potentialnya (ODP) adalah nol. Penggunaan foam memunculkan kekhawatiran terhadap kerusakan lapisan ozon bila dalam prosesnya masih menggunakan CFC's sebagai blowing agent, karena dalam proses pembuatan foam ternyata $90 \%$ CFC yang digunakan dilepaskan ke atmosfir yang kemudian akan mengikis lapisan ozon. Proses ini diawali dengan pecahnya CFC's ketika berinteraksi dengan sinar matahari di atmosfir atas dan kemudian dilepaskannya klorin yang akan menghancurkan ozon. Menurut Presiden National Wildlife Federation, sebuah cup terbuat dari foam mengandung 10 pangkat 18 molekul CFC's akan menghancurkan 100.000 molekul ozon. Keberadaan atom klorin penghancur ozon saat ini melaju 4-5 kali lebih tinggi dibandingkan dalam kondisi normal. Pada tahun 1985 lubang ozon sebesar benua Amerika telah dideteksi di atas antariksa. Sementara itu pada tahun 1988, di atas benua Eropah diperkirakan terjadi $3 \%$ penipisan lapisan ozon. Bila kecenderungan ini terus berlangsung akan meningkatkan insiden kanker kulit, kerusakan mata dan makin tingginya penyakit katarak, serta merebaknya kejadian infeksi karena rusaknya sistem kekebalan tubuh. Rusaknya lapisan ozon

Tabel 2 karakteristik dari CFC, HCFC dan HFC

\begin{tabular}{|l|l|l|l|l|}
\hline Jenis & $\begin{array}{l}\text { Impact } \\
(\% \text { CFC's })\end{array}$ & Penggunaan & Pengaruh & Kandungan \\
\hline CFC & $100 \%$ & 100 & $100 \%$ & Klorin bebas \\
\hline HCFC & $5 \%$ & 33 & $1,7 \%$ & klorin terikat \\
\hline HFC & $0 \%$ & 33 & $0 \%$ & Tanpa klorin \\
\hline
\end{tabular}


juga merupakan malapetaka bagi kehidupan fitoplankton yang hidup di permukaan samudera. Fitoplankton adalah salah satu mata rantai pangan di lautan yang bertanggung jawab terhadap $40 \%$ suplai oksigen di bumi. Bila kerusakan ozon mencapai $166 \%$ diperkirakan fitoplankton akan musnah. Seandainya fungsi CFC's sekarang dihentikan, konsentrasinya di atmosfir akan terus naik sampai abad mendatang karena penggunaan saat ini yang terlanjur tinggi khususnya di negaranegara maju. Molekul CFC's mampu bertahan 150 tahun sebelum mereka pecah. Untuk itu saat ini di negara-negara maju penggunaan CFC'ssangat dibatasi baik sebagai blowing agent maupun untuk penggunaan lain seperti refrigerator, AC dan lain-lain. Dan ini tentunya tidak hanya merupakan tanggung negara-negara maju tetapi juga negara berkembang seperti Indonesia.

\section{KESIMPULAN.}

Penggunaan foam sebagai bahan kemasan telah berdampak terhadap beberapa insiden pada makhluk hidup akibat dalam prosesnya kemasan jenis ini dapat menyebabkan terjadinya pengikis-an ozon yang berakibat tidak ada lapisan di atmosfir yang dapat meyerap radiasi matahari terutama sinar ultra violet yang sangat berbahaya bagi kesehatan manusia karena dapat menyebabkan kanker kulit, katarak, kerusakan - kerusakan terhadap material tertentu serta kehidupan laut.

\section{DAFTAR PUSTAKA}

1. Gessner G. Hawley, :The Condensed Chemical Dictionary", VNR, new York, tenth edition (1981)

2. Sybil P. Paker,"Dictionary of Scientific and Technical Term', Mc Graw Hill, Fith edition, USA (1993).

3. Aoron L. Brody, Kenneth S. Marsh, Encyclopedia: of Packaging Technology", John Wiley \& Sons, new York, Second edition (1997).

4. Widodo, Ir. "Dampak ODS terhadap Lingkungan"Deseminasi Substitusi Bahan Baku ODS pada industri Foam, Surabaya (2001)

5.----,"The Science of Ozone Depletion", http://www.epa.gov (2001)

6. ---,"Ozone Hole Largest Ye", http ://www.ozon-depletion.net (0021)

7. ---,"Living with Polyurethane ", http://www.europur.com (2001).

8. ---," Application of Diisocyanates", ttp"//ww.isopa.org (2001).

9. -----,"Ozone Depletion", http://ww. polyurethane .org (2001).

10. ---,"Freon as a Blowing Agent in Polyurethane Foam", http://www. foam-tech.com (2002) 